\title{
Agama dan Resolusi Konflik dalam Pilkada
}

\author{
Mohammad Najib
}

The article below traces religion and conlict resolution regarding the election of head of province or that of regency in Indonesia. The changing of public election system gives an opportunity and chance for people to vote their leader candidates directly. The above situation can emerge some crucial problems, for instance, when candidate proposing by political party, verification the candidate condition, the moment of campaign, the final decision of the elected candidate. In this connection, to prevent and to solve the crucial problems, religion and religious leaders can play important role, for example to keep political ethics, to conduct amar ma'ruf nahi munkar ( social control).

Kata kunci: agama, konflik, politik, dan budaya.

$\mathrm{M}$ ulai Juni 2005 terjadi perubahan yang sangat mendasar dalam pemilihan kepala daerah, yaitu dengan diberlakukannya Pilkada Langsung. Hal itu merupakan konsekuensi dari perubahan sistem pemilu di Indonesia, yang semakin memberikan perluasan hak rakyat dalam memilih para wakil dan pemimpin mereka. Pemberlakuan sistem proporsional dengan daftar terbuka dalam Pemilu DPR dan DPRD, tidak saja telah memberikan kebebasan rakyat untuk memilih parpol yang diinginkan, namun sekaligus secara langsung memilih calon DPR/ DPRD. Sementara Pemilu DPD dengan sistem distrik berwakil banyak memungkinkan bagi rakyat untuk langsung memilih calon yang diinginkan. Sedangkan Pemilihan Presiden dan Wakil Presiden secara langsung juga memungkinkan bagi rakyat untuk secara langsung memilih
Presiden dan Wakil Presiden yang diinginkan.

Perubahan sistem pemilu dengan memberikan perluasan hak politik rakyat untuk secara langsung memilih para kandidat tersebut memungkinkan terjadinya perubahan perilaku pemilih. Ketika rakyat secara langsung dapat memilih nama calon, maka sentimen dan fanatisme personal pada tokoh-tokoh kharismatik sangat mewarnai perilaku pemilih. Hal itu karena dalam budaya politik di Indonesia masih

1 Rusadi Kantaprawira, Sistem Politik Indonesia suatu model pengantar, Sinar Baru, Bandung, 1983, hal. 37. Dalam budaya politik kaula anggota masyarakat mempunyai minat, perhatian, mungkin pula kesadaran terhadap sistem sebagai keseluruhan, terutama tethadap segi outputnya. Sedangkan perhatian (yang frekuensinya sangat rendah) atas aspek input serta kesadarannya sebagai aktor politik, boleh dikatakan nol. Posisinya sebagai kaula, pada pokoknya dapat dikatakan pasif. Mereka 
lekat dengan budaya politik kaula,' atau budaya patronase (patron-client relationship). Sedangkan struktur masyarakat yang sangat majemuk, justru sebagai faktor pendorong bagi terjadinya perpecahan dan konflik dalam masyarakat yang dipicu oleh perbedaan afiliasi politik.

Pluralitas masyarakat tersebut akan berpotensi menjadi sumber energi konflik manakala perbedaan yang ada dimanfaatkan oleh elite untuk mencapai kepentingan politik tertentu dengan cara-cara kekerasan. $^{2}$ Menurut Suyanto, kehidupan politik di Indonesia sangat berpo-tensi bagi terjadinya konflik, baik secara vertikal maupun horisontal atau bahkan keduanya sekaligus. ${ }^{3}$ Arendt Lijphart dalam Consosionalisme Democracy mengatakan bahwa Indonesia termasuk kategori centrifugal democracy, yaitu keadaan di mana perilaku elitnya sangat kompetitif, sementara pada tataran political cultur, masyarakat berada dalam keadaan terfragmentasi (fragmented). ${ }^{4}$ Realitas obyektif tersebut jika tidak diantisipasi dengan serangkaian intervensi upaya untuk melakukan resolusi konflik dan peace building, maka Pilkada Langsung yang tengah memasuki kancah medan pentas politik praktis di Indonesia akan berubah menjadi medan laga konflik dan kekerasan politik yang cukup akut, yang tidak hanya melibatkan elite yang sedang berebut kekuasaan, namun sekaligus massa pendukung elite tersebut, di berbagai daerah. Terbukti konflik dan kekerasan politik sempat terjadi di beberapa daerah yang telah menyelenggarakan Pilkada.

\section{Titik Rawan Konflik}

Meskipun secara umum Pilkada Langsung tersebut sangat rawan bagi terjadinya kon-flik dan kekerasan politik, namun sesungguhnya ada beberapa titik rawan konflik. Titik-titik rawan konflik dalam tahap-tahap pelaksanaan Pilkada setidaknya meliputi; pertama, tahap pengajuan pasangan calon oleh parpol/ gabungan parpol. Persyaratan minimal perolehan suara/kursi sebanyak $15 \%$ bagi parpol/gabungan parpol untuk mengajukan pasangan calon ke KPUD dan setiap parpol/ gabungan parpol hanya diperbolehkan mengajukan satu pasa-ngan calon, membuat persaingan dan konflik kepentingan antar elite politik lokal pertama kali terjadi, ketika parpoi/gabungan parpol harus mengajukan pasangan calon. Hal itu karena terbatasnya peluang bagi bakal calon untuk lolos dalam proses seleksi yang dilakukan oleh parpol/gabungan parpol.

Ketidakmampuan parpol/gabungan parpol untuk membangun mekanisme demokra-tis dan transparan, ${ }^{5}$ dalam mengajukan pasangan calon, sebagaimana dikehendaki undang-undang, membuat tidak adanya standard penilaian yang jelas yang dapat disepakati bersama. Standard penilaian tersebut tidak saja penting bagi sesama pengurus parpol/gabungan parpol,

menganggap dirinya tidak berdaya mempe-ngaruhi atau mengubah sistem, dan oleh karena itu menyerah saja kepada segala kebijakan dan keputusan pemegang jabatan dalam masyarakatnya.

${ }^{2}$ Khoiruddin, Profil Pemilu 2004; evaluasi pelaksanaan, hasil dan perubahan politik nasional pasca Pemilu Legislatif 2004, Pustaka Pelajar, Yogyakarta, 2004, hal. 85.

${ }^{3}$ Suyanto, 'Membaca Potensi Konflik Menjelang Pemilu', Pikiran Rakyat, 6 Oktober 2003.

${ }^{4}$ Khoiruddin, op cit.

${ }^{5}$ Pasal 59 ayat (3) UU No. 32/2004. Meskipun dalam penjelasan ayat tersebut dinyatakan bahwa yang dimaksud dengan 'mekanisme yang demokratis dan transparan' dalam ketentuan ini adalah mekanisme yang berlaku dalam parpol/gabungan parpol yang mencalonkan dan proses penyelenggaraan dan keputusannya dapat diakses oleh publik. 
namun juga oleh bakal calon yang ikut bersaing dalam memperebutkan tiket untuk mewakili parpol/gabungan parpol dalam bursa pencalonan kepala daerah. Akibatnya tahapan ini selalu menyisakan ketidakpuasan dan konflik antar pengurus parpol/ gabungan parpol, serta dengan bakal calon yang gagal dalam persaingan untuk memperebutkan tiket pencalonan. Terbukti di berbagai daerah konflik antar pengurus parpol/gabungan parpol dan elite lokal (independen) dengan pengurus parpol terjadi dalam tahapan ini. Bahkan di beberapa tempat tahapan ini telah menumbuhkan bagi munculnya kepengurusan ganda di tubuh parpol serta gugatan oleh sejumlah elite politik terhadap pengurus parpol.

Titik rawan kedua terjadi dalam tahapan verifikasi persyaratan calon oleh KPUD. Terganggunya independensi KPUD oleh intervensi pemerintah dan elite politik loka ${ }^{6}$ dalam satu sisi membuat KPUD kurang dapat bekeja secara professional dalam melakukan veri-fikasi persyaratan calon, yang berisiko pada terjadinya putusan kelolosan calon yang kontro-versial. Pada saat yang sama ketidakmauan elite politik untuk mencer-mati dan mengikuti prosedur pencalonan dan lebih menekankan proses politik untukmelo-loskan pasangan calon yang diajukan memicu terjadinya konflik antara parpol/gabungan parpol dengan massa pendukungnya dengan KPUD yang mengacu pada prosedur peraturan-perundangan yang ada. Kedua hal tersebut membuat terjadinya pendudukan, perusakan dan kekerasan oleh pendukung pasangan calon atau parpol/gabungan parpol terhadap anggota dan statKPUD serta aparat kepolisian, atau kekerasan oleh aparat kepolisian terhadap para pendukung pasangan calon atau parpol/gabungan parpol yang sedang melakukan demo atau memaksakan kehendak untukmeloloskan pasangan calon yang didukungnya.
Titik rawan ketiga terjadi pada"saat kampanye. Kampanye adalah tahapañ bagi pa-sangan calon dan tim kampanye/tim sukses untuk mengupayakan pemenangan dalam Pilka-da. Dekatnya jarak antara para kandidat dengan pemilih akan membuat 'sumbu pendek' yang akan memicu konflik horisontal antar pendukung pasangan calon kepala daerah yang berbeda. Sama-sama pemilu milih langsung, Pilkada karakteristiknya lebih dekat dengan Pilurdes dari pada Pilpres. Perbedaan karakteristik tersebut sebagai akibat dari perbedaan yang cukup signifikan jarak antara kandidat dan pemilih.

Pilkada adalah perebutan kekuasaan yang melibatkan elite lokal yang punya kedekatan secara geografis dan emosional dengan massa akar rumput. Kentalnya budaya patron-client relationship di masyarakat basis akan selalu menumbuhsuburkan fanatisme massa pendukung antar kandidat, yang kemudian bermuara pada hadirnya simpul-simpul konflik dan kekerasan antar massa pendukung. Terbukti dalam pelaksanaan kampanye Pilkada di berbagai daerah selalu ditengarai dengan terjadinya perang urat syaraf, fitnah (black compign) dan ancaman antar pasangan calon dan/atau tim sukses yang punya kepentingan politik berbeda.

6 UU No. 32/2004 yang telah memutus hubungan KPUD dengan induknya (KPU) serta besarnya intervensi Depdagri dalam penyelenggaraan Pilkada di sisi lain, membuat independensi KPUD dalam penyele-nggaraan Pilkada mengalami pengurangan yang cukup signifikan. Hal itu diperkuat dengan munculnya PP No.6/2005 yang sangat membatasi kewenangan KPUD dan munculnya Desk Pilkada yang punya fungsi duplikasi dengan tugas KPUD. Lemahnya KPUD tersebut kemudian dimanfaatkan politisi lokal untuk mendesakkan keinginan politiknya pada KPUD lewat tekanan-tekanan politik. 
Medan pertempuranpun semakin luas, dengan keterlibatan para kader pendukung masing-masing pasangan calon untuk memenangkan pasangan calon yang didukungnya. Perbedaan preferensi pilihan politik baik elite maupun massa dalam Pilkada tersebut, seba-gaimana yang terjadi dalam Pilurdes, merupakan 'bara dalam sekam' yang jika salah dalam penanganan akan dengan mudah terkonversi menjadi konflik horisontal yang akan mengan-cam bangunan masyarakat sipil yang aman dan damai. Terlebih lagi dalam masyarakat kita sudah terjadi preseden konflikantar kelompok masyarakat dan luka lama yang terkoyak saat Pileg, Pilpres dan mungkin Pilurdes yang sesungguhnya belum sembuh benar.

Titik rawan keempat terjadi pada saat penghitungan dan penetapan pasangan calon terpilih. Dalam tahapan ini ketidakpuasan seialu muncul pada pasangan calon yang dinyatakan kalah. Frustasi dan ketidakpuasan bisa saja terjadi tidak hanya pada pasangan calon yang kalah, namun juga pada tim sukses dan para pendukungyangpunya harapan besar untukmenang. Frustasi tersebut akan sangat mudah terkonversi dalam bentuk ledakan kema-rahan yang bersitat destruktif jika menemukan 'titik api' pemicu konflik. Terlebih lagi untukdapat memenangkan Pilkada cukup dengan syarat perolehan suara minimal $25 \%$ plus satu ${ }^{7}$ sehingga memungkinkan terpilihnya pasangan calon dengan dukungan minimal untuk dapat ditetapkan sebagai pemenang. Akibatnya legitimasi pasangan calon terpilih bisa sangat ren-dah, sehingga memungkinkan mayoritas pemilih/rakyat justru tidak puas terhadap hasil Pilka-da, termasuk terpilihnya pasangan calon tertentu.

Titik-titik rawan tersebut tentu harus diantisipasi agar bahaya laten konflik dan kekerasan dalam Pilkada semaksimal mungkin dapat diantisipasi. Tanpa upaya tersebut tentu Pilkada akan menjadi medan konflik dan kekerasan politik baru yang terjadi di berbagai daerah. Sehingga berbagal upaya rekayasa sosial untuk melakukan resolusi konflik serta peace keeping dalam rangka untuk mendorong berlangsungnya Pilkada damai menemukan urgensinya. Agama tentu punya peran strategis dalam berpartisipasi dalam implementasi proyek untuk mendorong humanisasi kehidupan politik lokal pada setiap penyelenggaraan Pilkada. Misi suci setiap agama untuk menata kehidupan agar lebih baik, tentu tidak dapat melepaskan diri dari tanggung jawab untuk mendorong pentas panggung politik Pilkada untuk dapat berjalan secara damai dan demokratis.

\section{Ambivalensi Agama}

Terjadi perdebatan yang menyangkut posisi agama dalam konflik dan kekerasan politik. Di satu sisi ada sekelompok orang yang berpendapat bahwa agama punya peran terhadap terjadinya berbagai konflik dan kekerasan politik. Di sisi lain ada yang berpendapat bahwa agama sebagai kredo humanis dan realitas tak tergugat sangat menentang terorisme, pembunuhan serta kekerasan politik, karena kesemua itu bukanlah atas nama agama. Tindakan semacam itu bukan atas nama Islam, bukan Kristen, bukan Hindu, bukan Buddha, bukan Sikh, karena tindakan tersebut telah melanggar kesucian dan martabat agama. ${ }^{8}$

Dua pandangan tersebut dibangun atas dasar asumsi yang berbeda. Pandangan pertama menganggap agama sebagai kekuatan destruktif, atau hantu masa Jalu yang absurd, sedangkan yang kedua

-7 Pasal 107 ayat (2) UU No. 32/2004.

B Zakiyuddin Bajdhawy, Ambivalensi Agama, Konflik dan Nirkekerasan, LESFI, Yogyakarta, 2002, hal. 1. 
menganggap agama sebagai kekuatan kreatif dan berkeadaban. Kedua pendapat tersebut gagal dalam memahami realitas agama yang sesungguhnya. Kelompok pertarna telah gagal dalam menghargai sifatsifat manusiawi dari agama dan pedoman moral-nya yang menekankan perilaku tidak toleran terhadap kekerasan. Sementara kelompok kedua telah gagal dalam memahami ajaran agama yang otentik, yakni respon yang tulus terhadap yang suci, bertujuan untuk menaklukkan kehidupan manusia di hadapan hukum Tuhan. ${ }^{9}$

Jika agama melegitimasi kekerasan, ia juga berusaha membatasi frekuensi dan ruang lingkup aksi tersebut. Sikap ambivalensi agama tersebut mencerminkan 'manfaat' agama sebagai instrumen pertahanan diri dan penguatan norma-norma agama di satu sisi, juga mengakui potensi destruktifnya yang tak terkendali di sisi lain. Dalam banyak agama terdapat ketegangan antara penggunaan dan sublimasi kekerasan dan 'martir suci' yang berkorban demi kehidupan orang lain, khususnya pengorbanan pada para elite yang menjadi patron ummat. Tidak ada istilah yang tepat untuk menyampaikan ambivalensi tersebut. Sementara dalam bahasa keseharian, ungkapan 'militan, ekstrem, radikal' dan 'fundamentalis' digunakan secara longgar dan saling menggantikan. Masalah inj menimbulkan kebingungan, karena ungkapan tersebut sering disamakan dengan 'teroris'. Diperiukan pendekatan yang lebih menekankan nir kekerasan untuk menyelesaikan kontlik yang terjadi dalam masyarakat oleh para pimpinan agama, demi menegakkan keadilan dan perdamaian.

Penggunaan pendekatan nir kekerasan dalam mengatasi berbagai konflik oleh para elite agama ini menemukan sandaran teologisnya, jika kemudian dikaitkan dengan misi suci agama untuk memberikan perlin- dungan bagi penunaian hak dasar. umat manusia. Dalam Islam hal tersebut dikenal dengan maqashid al-syari'ah, yang meliputi lima hal, yakni (1) melindungi agama (hifzh al-din), (2) melindungi jwa dan keselamatan fisik (hifzh al-nafs), (3) melindungi kelangsungan keturunan (hifzh al-nasl), (4) melindungi akal pikiran (hifzh al-'aql), dan (5) melindungi harta benda (hitzh al-mal). ${ }^{10}$ Rumusan lima magashid tersebut memberikan pemahaman, bahwa Isiam telah cukup memberikan landasan dasar bagi umatnya untuk menyelenggarakan kerja-kerja kemanusiaan, yang tujuannya untuk menjamin perlindungan hak dasar umat manusia. Semangat yang sama tentu dapat ditemui dalam etika Kristiani dengan 'kasihnya', dalam etika Hindu dengan semangat ahimsa (non-violence)-nya, dalam etika Buddhis dengan etos kesederhanaannya serta dari etos dan semangat agama yang lain, yang tentu saja sangat menentang tindak kekerasan.

Dalam konteks terjadinya fenomena konflik dan kekerasan yang muncul dalam Pilkada, semua agama sesungguhnya bisa bahu-membahu untuk memberikan perhatian pada upaya resolusi konflik, guna menjamin pemenuhan hak dasar umat manusia,setidaknya dalam aspek perlindungan atas jiwa dan keselamatan, serta perlindungan atas kebebasan untuk menentukan pilihan politik. Jika hal itu dapat diperankan dengan baik oleh para elite agama, maka agama akan punya peran besar dalam menjalankan misi kemanu-

\section{9 lbid, hal. 2.}

${ }^{10}$ Dr. KH. MA. Sahal Mahfudh, 'Bahtsul Masail dan Istinbath Hukum NU : sebuah catatan pendek', dalam Solusi Problematika Aktual Hukum Islam: Keputusan Muktamar, Munas dan Konbes NU 1926-1999), LTN NU dan Diantama, Surabaya, Cetakan II, 2005, hal. xvii. 
siaan, untuk memberikan perlindungan atas jiwa dan keselamatan umat, serta perlindungan atas kebebasan berfikir dan menentukan pilihan politik, sebagai bagian dari ijtihad politik untuk berhikmah bagi upaya membangun kehidupan masyarakat masa depan yang lebih baik. Bagaimanapun fungsi sosial dari semua agama dalam tatanan masyarakat masa kini harus dapat mengawal berlangsungnya tradisi demokrasi bagi umat manusia, guna membangun masyarakat terbaik (khaira ummah). Pilkada adalah bagian darieksperimentasi demiokrasi di tingkat lokal yang dalam implementasinya butuh pengawalan dari agama agar dapat berlangsung secara damai dan demokratis.

\section{Peran Agama}

Setidaknya ada dua alasan mengapa agama perlu diberi peran dalam melakukan reso-lusi konflik dalam Pilkada. Alasan pertama, adanya pertanda, bahwa modernisasi sosial-ekonomi di berbagai masyarakat yang berpenduduk mayoritas muslim, justru mendorong peningkatan religiusitas, bukan sekularisme, seperti ramalan teoritisi modernisasi. Walaupun peningkatan religiusitas juga dicatat di berbagai kalangan pemeluk agama lain, namun yang terjadi pada umat Islam sangat mencolok. Persoalannya adalah, bahwa proses itu ternyata memuat potensi yang mengganggu keselarasan dalam hubungan antar umat beragama. Dalam masyarakat seperti itu, misalnya, militansi cenderung meningkat, fundamentalisme berkembang, toleransi antar pemeluk agama menurun. ${ }^{11}$

Alasan kedua, adanya dugaan bahwa proses yang sama juga menghasilkan pengen-duran hubungan antara sebagian pemeluk agama dengan lembaga-lembaga keagamaan yang melayaninya. Kemerosotan otoritas lembaga agama semakin terasa di berbagai kalangan umat beragama.
Otoritas para pemimpin lembaga agama terhadap umat yang mengalami modernisasi-urbanisasi, terutama lapisan usia muda, terasa mengendur. Di beberapa tempat di Jawa, demonstration-effect yang diakibatkan oleh proses modernisasi membuat hubungan para kiai dengan santri atau pengikutnya tidak seerat dahulu. Hal yang mencolok terjadi dalam hubungan antara santri dengan ulama yang dalam pandangan pengikutnya sudah dikooptasi oleh negara. ${ }^{12}$ Hal yang sama juga terjadi di berbagai kalangan agama lain. Merosotnya kohesi di kalangan umat beragama ini dikhawatirkan akan membuat pengelolaan konflik antar umat beragama semakin sulit dilakukan. Berdasarkan realitas tersebut, maka agama lewat para pimpinannya harus lebih serius dalam melakukan upaya intervensi dalam kehidupan umatnya, untuk mewujudkan terjadinya resolusi konflik dalam Pilkada.

Hal itu sebagai konsekuensi, bahwa terlaksananya Pilkada secara damai dan demokratis adalah tanggung jawab semua pihak untuk mewujudkannya. Misi suci agama untuk mengawal kehidupan manusia, agar berlangsung secara baik dan manusiawi tentu tidak dapat melepaskan diri dari tanggung jawab untuk mewujudkan berlangsungnya Pilkada damai dan demokratis tersebut. Ada beberapa peran yang dapat dimainkan oleh agama untuk mewujudkan Pilkada agar dapat berlangsung secara damai dan demokratis.Peran tersebut meliputi; pertama, pendidikan politik (pendidikan pemilih). Fungsi pengajaran (tabligh) dari agama harus mampu

11 Mohtar Mas'oed, Mochammad Maksum, Moh Soehadha, Kekerasan Kolektif : Kondisi dan Pemicu, P3PK UGM, Yogyakarta, 2001 , hal. 16.

12 Ibid, halaman 17. 
memberikan bimbingan pada umat agar ketika berpartisipasi dalam Pilkada dengan menjunjung tinggi etika dan moral keagamaan, sehingga praktek berpolitik dalam kerangka Pilkada diharapkan dapat berlangsung secara baik.

Bimbingan agama pada umat agar selalu menjaga moralitas politik dalam praktik kehidupan politik praktis ini menemukan urgensinya dalam rangka mendorong berlangsungnya Pilkada damai dan demokratis, lewat perbaikan semangat dan visi kemanusiaan dari para politisi. Para juru dakwah dari semua agama perlu merevitalisasi dan mensosialisasikan teksteks keagamaan yang menganjurkan pentingnya etika berpolitik (fatsoen politik) dan pendekatan nir kekerasan dalam aktivitas politik praktis. Hal tersebut merupakan langkah preventif untuk menghindari kemungkinan terjadinya kekerasan politik dalam realitas kehidupan politik dalam Pilkada.

Langkah kedua berupa intervensi penyelamatan atas realitas konflik dalam dari agama sangat dimungkinkan unkık bisa diterima oleh pihak-pihak yang berkonfilik untuk ikut membantu melakukan resolusi konflik. Intervensi peran agama terhadap resolusi antar kelompok yang berkonflik tersebut meliputi arbitrase, negosiasi dan mediasi. ${ }^{13}$ Dalam arbitrase agama, yang diwakili oleh para elitenya punya otoritas penuh untuk melakukan intervensi pada kedua belah yang berkonflik untuk melakukan intervensi upaya resolusi konflik yang secara efektif diterima oleh kedua belah pihak. Sedangkan peran mediasi akan sangat membantu dalam resolusi konflik, khususnya antar pihak yang mengalami hambatan komunikasi. Perbedaan terhadap ketiga peran tersebut menyangkut mandat/ otoritas dan arah komunikasi untuk melakukan resolusi konflik. Ketiga hal tersebut dapat digambarkan sebagai berikứ;

Agama dengan para tokohnya yang terjaga netralitas politiknya (non partisan) dan terjamin kredibilitasnya dalam menjaga nilai-nilai kemanusiaan adalah pihak ketiga yang dapat diterima oleh kedua belah pihak yang berkonflik dalam rangka membantu

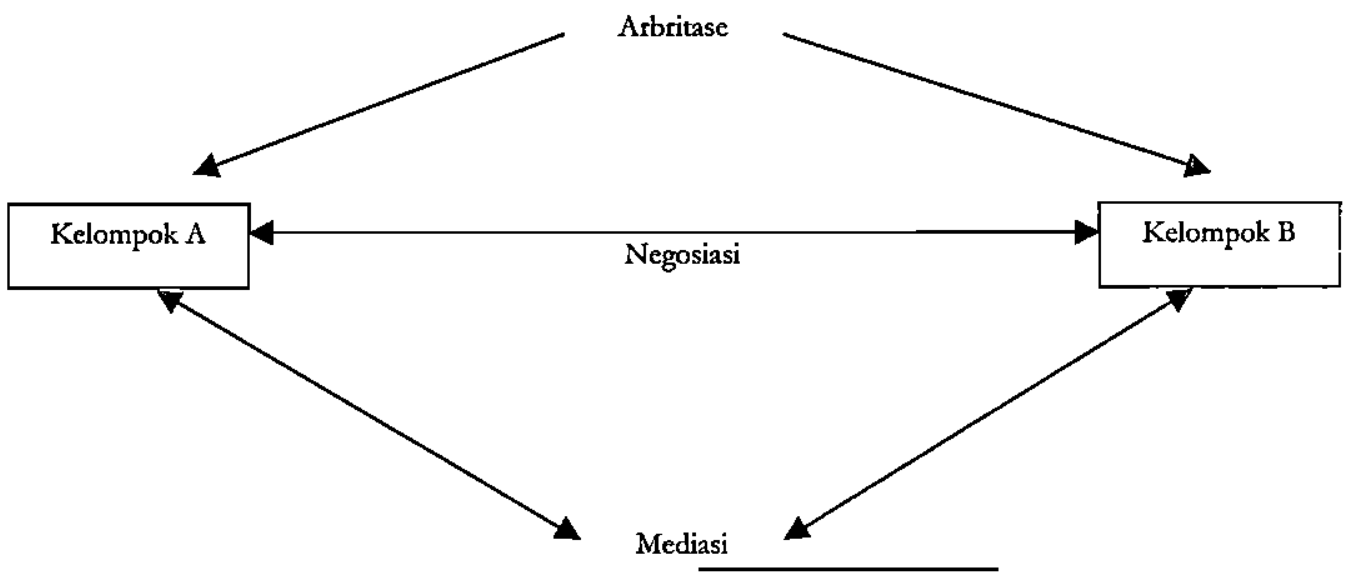

Pilkada (resolusi konflik). Jika konflik sudah terjadi dalam masyarakat, agama harus mengambil bagian dalam upaya melakukan resolusi konflik. Posisi netral (non partisan)

${ }^{13}$ Hugh Miall, Oliver Ramsbotham, Tom Woodhouse, Contemporary Conflict Resolution, Polity Press, Cambridge, UK, 1999, hal. 11 juga Peter Harris dan Ben Reilly (editor), 
melakukan resolusi konflik. Posisi tersebut harus dimainkan dengan baik oleh agama lewat para tokohnya dalam berhikmah untuk dan multi jalur dari Lederach, 1998,, sebagai berikut;
Negosiasi tingkat tinggi

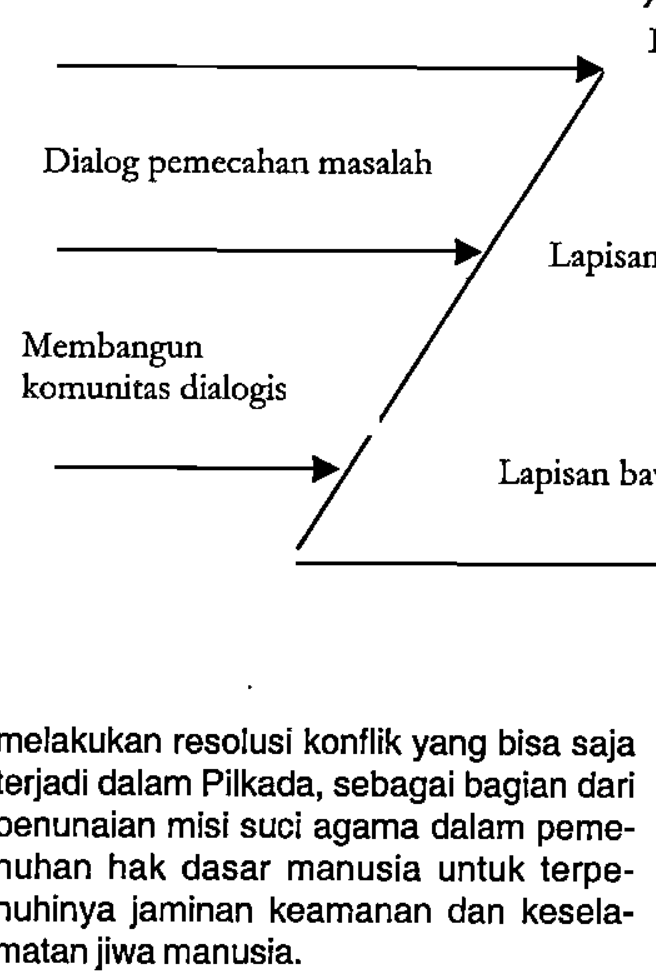

Untuk efektivitas pencapaian hasil, resolusi konflik tersebut dapat dilakukan dengan banyak jalur (multitrack). Resolusi konflik tersebut bisa dilakukan pada lapis atas, menengah dan bawah, dengan pendekatan rekonsiliasi yang berbedabeda. ${ }^{14}$ Negosiasi tingkat tinggi dilakukan pada lapisan elite politik tingkat atas. Dialog pemecahan masalah pada lapisan menengah, dan membangun komunikasi dialogis untuk warga komunitas lapis bawah. llus-trasi tentang hal tersebut dapat dilihat dalam piramida resolusi konflik multi-level

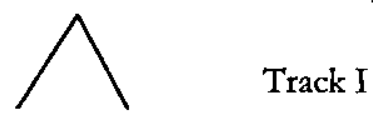

Lapisan

atas
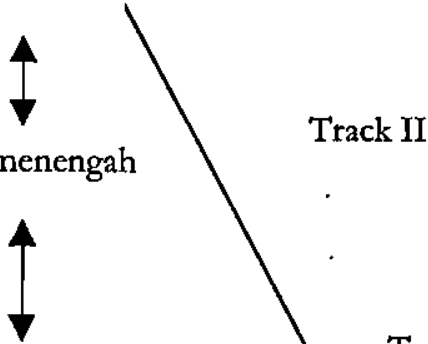

Track III
Langkah ketiga berupa penunaian fungsi pengawasan sosial. Peran amar ma'ruf nahy munkar dari agama harus mampu menjadi pengontrol atas perilaku umat yang menyimpang. Dalam konteks pelaksanaan Pilkada, agama harus mampu mengontrol perilaku umatnya yang cenderung untuk melanggar peraturanperundangan (seperti larangan kampanye) serta melanggar etika moral berpolitik yang

Demokrasi dan Konflik yang Mengakar: sejumlah pilihan untuk negosiator, International Idea, Jakarta, 1998, hal. 110-112.

${ }^{14}$ Lambang Trijono, "Konflik Horizontal dan Rekonsiliasi Multitrack", dalam Dr. A. Munir Mulkhan dkk, Kekerasan dan Konflik; tantangan bagi demokrasi, Forum LSM DIYYAPPIKA, Yogyakarta, 2001, hal. 153.

${ }^{15} \mathrm{Ibid}$, hal. 154. 
memicu terjadinya konflik dan kekerasan politik antar elite dan/atau massa pendukung. Atas dasar realitas tersebut, agama lewat para tokoh agama harus mampu menjalankan peran advokasi untuk menutup peluang terjadinya intimidasi dan kekerasan politik. Agama harus mampu menjadi pengawal bagi berlangsungnya Pilkada damai dan demokratis. Hal itu akan tercapai jika agama mampu mengawal etika berpolitik dari ummatnya dan sekaligus memberikan perlindungan pada umatnya untuk menentuan pilihan-pilihan politik secara bebas dan bertanggung jawab, tanpa ada tekanan oleh pihak manapun, termasuk oleh para tokoh agama.

Ketiga peran tersebut akan dapat berjalan dengan baik manakala agama mampu menjaga netralitas politik dan mencegah keterlibatannya dalam aktifitas politik praktis yang sangat profan. Agama yang sakral harus 'dibebaskan' dari urusan politik praktis, yang cenderung manipulatif dan mempolitisasi agama untuk kepentingan politik kelompok tertentu. Ketika agama sudah ditarik dan masuk pada wilayah pentas politik praktis yang bersifat profan, maka dengan mudah akan dapat dimanipulasi untuk kepentingan politik tertentu. Ketika situasi tersebut terjadi, maka agama akan kehilangan sakralitas dan fitalitasnya dalam menjalankan misi pendidikan, penyelesaian masalah kemanusiaan serta advokasi kezaliman. Ihdinash shirat al mustaqiem. Semoga kita diberi kekuatan untuk menjaga agama kita, serta diberi kemampuan untuk mendayagunakannya untuk sebasar-besarnya bagi berlangsungnya Pilkada yang damai dan demokratis, sebagai bagian dari upaya membangun tradisi demokrasi secara damai.

\section{Daftar Pustaka}

A. Munir Mulkhan, dkk, Kekerasan dan Konflik; tantangan bagi Demokrasi, 2001, Yogyakarta:Forum LSM DIYYAPPIKA, .

Hugh Miall, Oliver Ramsbotham, Tom Woodhouse, 1999, Contemporary Conflict Resolution, Cambridge, UK:Polity Press, 1999, hal. 11 juga Peter Harris dan Ben Reilly (editor), 1998, Demokrasi dan Konflik yang Mengakar: Sejumlah Pilihan untuk Negosiator, Jakarta: International Idea.

Khoiruddin,2004, Profil Pemilu 2004; evaluasi pelaksanaan, hasil dan perubahan politik nasional pasca Pemilu Legislatif 2004, Yogyakarta: Pustaka Pelajar.

Mohtar Mas'oed, Mochammad Maksum, Moh Soehadha,2001, Kekerasan Kolektif : Kondisi dan Pemicu, Yogyakarta : P3PK UGM.

KH. MA. Sahal Mahfudh, 2005,'Bahtsul Masail dan Istinbath Hukum NU : sebuah catatan pendek', dalam Solusi Problematika Aktual Hukum Islam: Keputusan Muktamar, Munas dan Konbes NU 1926-1999), LTN NU dan Diantama, Surabaya, Cetakan II.

Rusadi Kantaprawira,1983, Sistem Politik Indonesia suatu model pengantar, Bandung : Sinar Baru,.

Zakiyuddin Baidhawy,2002, Ambivalensi Agama, Konflik dan Nirkekerasan, Yogyakarta: LESFI. 
Topik: Agama dan Teologi Populis Transformatif

UU No. 32/2004.

PP No.6/2005.
Suyanto, 'Membaca Potensi Konflik Menjelang Pemilu', Pikiran Rakyat, 6 Oktober 2003.

\section{$\square \square \square$}

